\title{
Elemental composition of individual pico- and nano-sized marine detrital particles in the northwestern Mediterranean Sea
}

\author{
Behzad MOSTAJIR $^{\text {a }}{ }^{*}$, Kjell Magne FAGERBAKKE ${ }^{\text {b }}$, Mikal HELDAL ${ }^{b}$, Trond Frede THINGSTAD ${ }^{\text {, }}$, \\ Fereidoun RASSOULZADEGAN ${ }^{\text {a }}$ \\ ${ }^{a}$ Université Pierre et Marie Curie, Paris VI, CNRS-URA 716, Station Zoologique, B.P. 28, \\ 06230 Villefranche-sur-Mer, France \\ ${ }^{\mathrm{b}}$ Department of Microbiology, University of Bergen, Jahnebakken 5, 5020 Bergen, Norway \\ ${ }^{\S}$ Present address: Institut National de la Recherche Scientifique, INRS-Océanologie, 31, allée des Ursulines, Rimouski, \\ Québec, G5L 3A1, Canada
}

(Received 01/08/97, revised 12/11/97, accepted 09/12/97)

\begin{abstract}
The elemental composition of individual $<10 \mu \mathrm{m}$ detrital particles from Mediterranean surface waters was analysed using a Transmission Electron Microscope (TEM) equipped with an energy dispersive X-Ray microanalyser. Results show that carbon and phosphorus content per detritus volume are much higher in pico-detrital particles $<2 \mu \mathrm{m}$ (42 $\mathrm{kg} \mathrm{C} \mathrm{m}^{-3}$ and $1 \mathrm{~kg} \mathrm{P} \mathrm{m}^{-3}$ ) than in 5-10 $\mu$ m detrital particles $\left(20 \mathrm{~kg} \mathrm{C} \mathrm{m}^{-3}\right.$ and $\left.0.1 \mathrm{~kg} \mathrm{P} \mathrm{m}^{-3}\right)$. The C:N:P atomic ratios for different sized fractions of the detrital particles were found to be 82:10:1 for $<2 \mu \mathrm{m}$ particles, 120:29:1 for $2-5 \mu \mathrm{m}$ particles and 308:37:1 for 5-10 $\mu \mathrm{m}$ particles. The average ratio for all size classes of detrital particles $(<10 \mu \mathrm{m})$ was 132:23:1. The differences in elementary compositions of the detrital particles studied here suggest that the different size fractions probably have different origins. The role and origins of $<10 \mu \mathrm{m}$ detrital particles within the biogeochemical cycles are discussed. (C) Elsevier, Paris
\end{abstract}

detritus / elemental composition / TEM / X-ray / Mediterranean

Résumé - Composition élémentaire des pico- et nano-détritus en Méditerranée nord-occidentale. La composition élémentaire des particules détritiques < $10 \mu \mathrm{m}$ provenant de l'eau de surface de la Méditerranée a élé analysée à l'aide d'un microscope électronique à transmission, équipé d'un micro-analyseur aux rayons $\mathrm{X}$. Les résultats montrent que les quantités de carbone et de phosphore par volume de détritus sont plus importantes pour les pico-détritus $<2 \mu \mathrm{m}\left(42 \mathrm{~kg} \mathrm{C} \mathrm{m}^{-3}\right.$ et $\left.1 \mathrm{~kg} \mathrm{P} \mathrm{m}^{-3}\right)$ par rapport à la classe de taille $5-10 \mu \mathrm{m}\left(20 \mathrm{~kg} \mathrm{C} \mathrm{m}^{-3}\right.$ et $\left.0,1 \mathrm{~kg} \mathrm{P} \mathrm{m}^{-3}\right)$. Le rapport atomique de C:N:P pour les différentes fractions de taille des particules détritiques est de 82:10:1 pour les détritus $<2 \mu \mathrm{m}$, de 120:29:1 pour les détritus 2-5 $\mu \mathrm{m}$ et de 308:37:1 pour la classe de taille de 5-10 $\mu \mathrm{m}$. Le rapport moyen pour toutes les classes de taille de détritus $<10 \mu \mathrm{m}$ est de 132:23:1. Les différences de composition élémentaire des détritus étudiés ici suggère que les différentes fractions de taille ont probablement différentes origines. Le rôle et l'origine des détritus $<10 \mu \mathrm{m}$ sont discutés dans le cadre des cycles bingénchimiques. (c) Elsevier, Paris

détritus / composition élémentaire / microscope électronique à transmission / rayons $\mathrm{X} /$ Méditerranée

* Correspondence and reprints 


\section{INTRODUCTION}

In any comprehensive budgeting of pelagic biogeochemical cycles, there is a need to consider the contribution of dead particulate matter to the standing stocks and fluxes of the elements involved. During the last decade, non-living organic particles have been increasingly studied because they provide a favourable base and nutrient supply for living organisms (e.g. marine snow, [2]). Moreover, they play a key role in the vertical transport of elements in aquatic environments (e.g. large detrital particles, [10]).

Although some quantitative studies of pico- and nanodetrital particles have been undertaken (submicronic particles [18, 29], colloids [34], and Dapi Yellow Particles "DYP" [23] the elemental composition of these $<10 \mu \mathrm{m}$ particles has received little attention.

Quantification is not straightforward since it requires the separation of non-living from living material. Estimation via subtraction of the living material from total particulates introduces errors associated with analysis of both total and living particulate matter. Accurate analysis of living matter is particularly difficult, even for a major element like carbon. In practice, microscopic estimation of size and abundance of organisms has been used, however it suffers from large errors in recognition, in size measurement and in the conversion factors required to convert volume to element content [27]. Measurement of substances common to all living organisms, such as ATP [16], is another possibility for quantification, but again there are large uncertainties related to the magnitude and variability of the conversion factors required. An alternative method when many samples are available, is to use the offset from the origin of the regression line between element content in total particulates and an assumed detrital-free parameter such as ATP, to give an estimate of the detrital component [28]. All of these methods give either bulk measurements or only crude size fractionations, and in the light of the large errors inherent in quantifying major elements like carbon, nitrogen and phosphorus from these approaches, they are practically useless for minor elements such as iron.

We explored here an alternative approach based on X-ray microanalysis with a transmission electron microscope $[15,25]$ to determine the elemental composition of individual small detrital particles of which abundances in different size classes had been previously determined using a fluorescence staining technique [23]. These techniques offer considerable potential for the study of both standing stocks and production/degradation mechanisms of small detrital particles since they allow abundance estimates to be coupled to the measurement of the content of all elements (with an atomic weight equal to and/or higher than carbon) in individual particles. At the same time, the particles can also be classified according to size and structure.

\section{MATERIAL AND METHODS}

\subsection{Sampling and Sample Processing}

Surface water was collected with a Niskin bottle at Point B, a standard oceanographic station at the entrance of the Bay of Villefranche $\left(43^{\circ} 41^{\prime} 10^{\prime \prime} \mathrm{N}, 7^{\circ} 19^{\prime} 00^{\prime \prime} \mathrm{E}\right)$ northwestern Mediterranean Sea in November 1994.

\subsection{Epifluorescence Microscope}

The samples examined by epifluorescence microscopy were prepared according to Mostajir [23]. Briefly, $10 \mathrm{~mL}$ of sample were fixed with formalin ( $3 \%$ final concentration), stained with DAPI (final conc. $0.25 \mu \mathrm{g} \mathrm{mL}^{-1}$ ), and immediately filtered onto a $25 \mathrm{~mm}$ black Nuclepore polycarbonate membrane $(0.2 \mu \mathrm{m}$ pore size $)$ using low vacuum $(<0.2$ bar). The filter was then placed on a slide and examined with an epifluorescence microscope (Zeiss Axiophot T/R with a $3 F 1$ reflector and DAPI filter set 487902: BP365, FT395, LP420) using a $100 \times$ Neofluar objective. Dapi Yellow Particles "DYP" were enumerated in different size-classes $(0.2-2 \mu \mathrm{m}, 2-5 \mu \mathrm{m}, 5-$ $10 \mu \mathrm{m})$. Fields were examined until a minimum of 100 particles in each size class were counted. To calculate the volume of particles, they were considered to be spheres with mean diameters for each of the above size classes measured by Transmission Electron Microscope, respectively: $1.68,3.23$ and $6.20 \mu \mathrm{m}$. In the same sample, heterotrophic bacteria were counted with an epifluorescence microscope according to Mostajir et al. [24].

\subsection{Transmission Electron Microscope (TEM) and $\mathrm{X}$-Ray Microanalysis}

To remove large particles, an unfixed water sample was gravity filtered through a $12 \mu \mathrm{m}$ polycarbonate filter. The particles $(<12 \mu \mathrm{m})$ of the filtered sample were harvested by centrifugation at $20,000 \mathrm{rpm}$ (swing out bucket rotor) at $4{ }^{\circ} \mathrm{C}$ for $1 \mathrm{~h}$ on 150 mesh $\mathrm{Cu}$ grids (Agar Scientific) 
supported with pioloform film and carbon coated. The coated grids werc glow discharged before use [14]. The grids were air dried at ambient conditions and transported with Silica-gel for ulterior analysis. Particles were analysed in a JEOL $100 \mathrm{CX}$ Transmission Electron Microscope (TEM), equipped with a Tracor Z-MAX 30 detector featuring silicon crystal and Norvar single window for light element detection. This method permits quantification of the major elements of individual particles. The microscope was operated at $80 \mathrm{kV}$, magnification 3000-15000, and the grids were placed between high purity carbon plates at a 38 degree nominal take-off angle. X-ray spectra were accumulated for $50 \mathrm{~s}$ in a Norvar multichannel analyser and stored on floppy disks. The scanned area, particle length and width were measured on

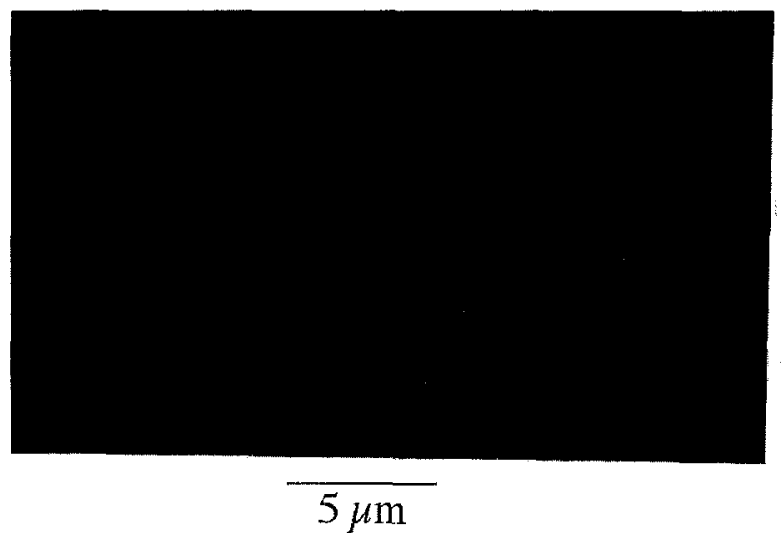

(A)

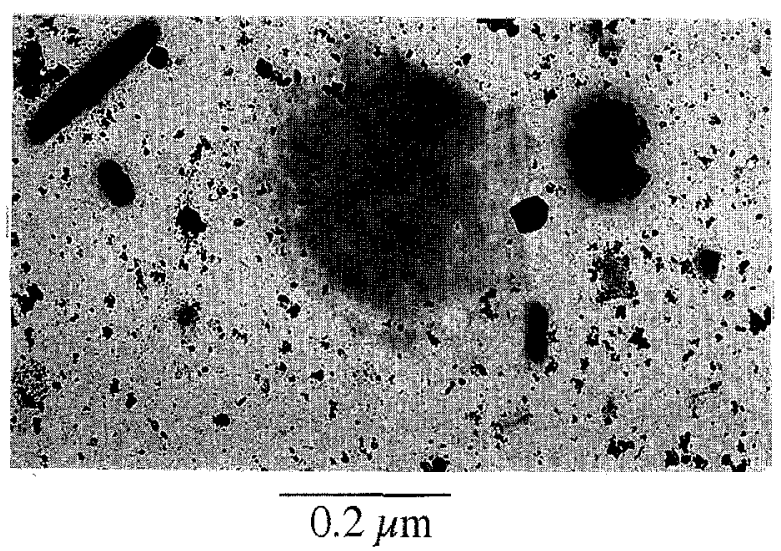

(C) the CRT screen of X-Ray analyser. A clear area (without any particles) near the measured particle was chosen for the film background spectrum. Neither fixatives nor stains were applied. Selection of analysed particles was based on their shape, structure and size. Microorganisms with a cell wall are distinguishable from pico- and nanodetrital particles which are essentially amorphous and without a cell wall as seen in the TEM image (figures $1 b$, 1c). For analysis, we selected detrital particles of similar shapes to those counted as DYP $<10 \mu \mathrm{m}$ under the epifluorescence microscope (figure 1a). Generally, in TEM, organic detrital particles are also distinguishable from dark, pellet-like inorganic particles by their lower electron density (the detrital particles shown in figures $l b, c$ compared to an inorganic particle shown in figure $1 d$ ).

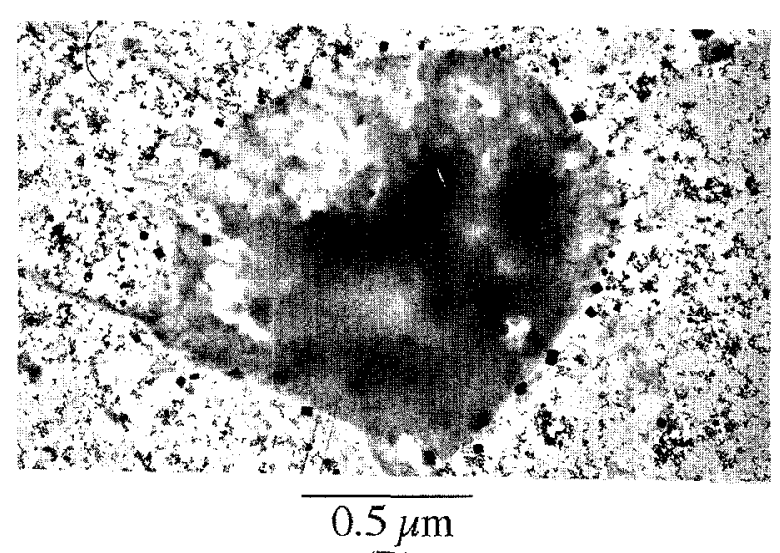

(B)

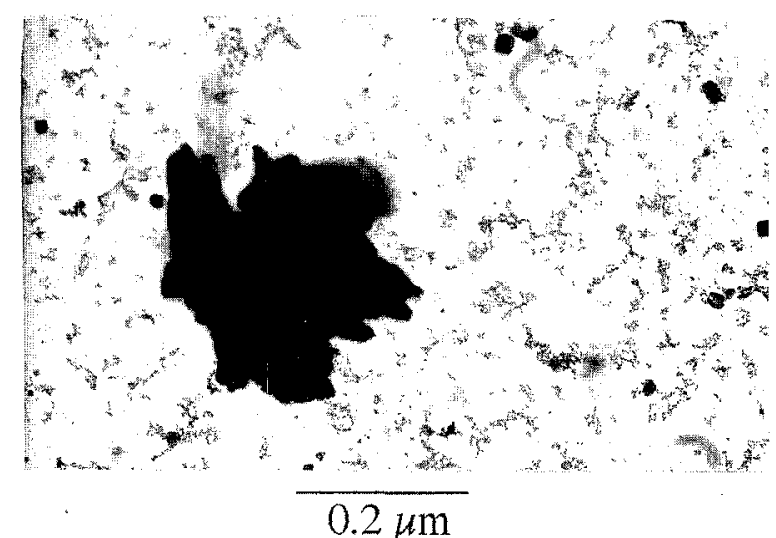

(D)

Figure 1. Photomicrographs of a sample from the northwestern Mediterranean Sea. Photos were taken using an epifluorescence microscope (A) and by TEM (B-D). (A): a detrital particle (Dapi Yellow Particle); (B); a detrital particle; (C): comparison of microorganisms with cell walls and detrital particles without any membrane; (D): an inorganic particle with higher electron density than detrital particles. 


\subsection{Data analysis}

\subsubsection{Processing of spectra}

The spectra were transformed to MS-DOS compatible binary files using a laboratory computer (MINC, Digital Equipment Corporation). All software and calibration procedures involved were developed at the University of Bergen [15, 25]. For the dry matter estimation, the sodium $(\mathrm{Na})$ and chlorine $(\mathrm{Cl})$ signals were omitted (assuming they represent residual seawater contamination) as was the copper $(\mathrm{Cu})$ signal, which reflects the $\mathrm{Cu}$-grid background. Total dry matter was estimated by adding all of the remaining elements and assuming a hydrogen content equal to $1 / 6$ of the carbon content.

\subsubsection{Classification of particles}

To investigate natural groupings among the different analysed particles, the data set (47 analysed particles with eleven measured elements) was standardised. Hierarchical flexible clustering, with $B=-0.25$ on a matrix of Euclidean distances among the standardised data was performed according to Legendre and Legendre [21].

\section{RESULTS AND DISCUSSION}

Results of the particle classification are shown in figure 2 . Two major groups can be separated at Euclidean distance 7 corresponding roughly to organic detrital particles and inorganic particles. To compare the chemical composition of detrital and inorganic particles in different size classes, each element value was divided by its respective particle volume. The mean of the new values was then calculated for each of three size classes of $<2 \mu \mathrm{m}$, 2-5 $\mu \mathrm{m}$ and 5-10 $\mu \mathrm{m}$ (figure 3). We rarely found inorganic particles below $2 \mu \mathrm{m}$, generally they ranged in diameter from 2-8 $\mu \mathrm{m}$. Inorganic particles have higher amounts of $\mathrm{O}, \mathrm{Si}, \mathrm{Al}, \mathrm{K}, \mathrm{Ca}, \mathrm{Mg}$ and $\mathrm{Fe}$, and consequently a higher weight than detrital particles of similar size. In contrast, detrital particles are rich in $\mathrm{C}, \mathrm{N}$ and $\mathrm{P}$.

The high Fe content of inorganic particles suggested that they could originate from Saharan dust or from terrestrial drainage. An important observation about the elementary composition of inorganic particles studied here is the absence of $P$. It has been suggested that inorganic particles with an $\mathrm{Fe}$ component can remove $\mathrm{P}$ from the water column [19]. In apparent contradiction to this, we found

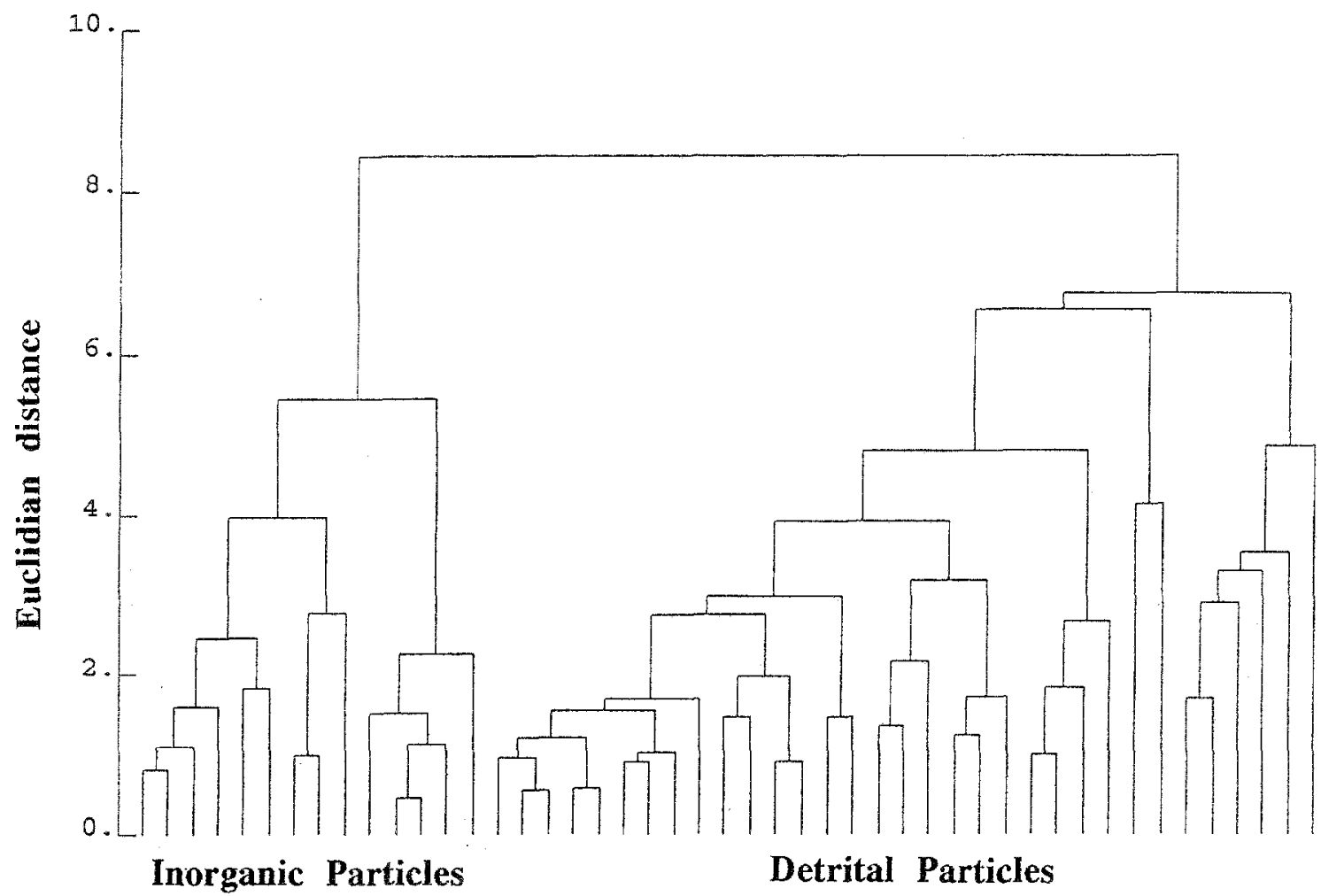

Figure 2. Hierarchical flexible clustering of all pico- and nano-particles analysed in this investigation, based on their elementary contents. Two major groups of detrital particles and inorganic particles are distinguishable by classification. 
Table I. Results of chemical composition of 31 analysed detrital particles in three size fractions. Unity of elements is $\mathrm{kg} \mathrm{m}^{-3}$ of detrital particles

\begin{tabular}{lccccccccccc}
\hline $\begin{array}{l}\text { Particle } \\
\text { sizes }\end{array}$ & C & N & O & Mg & Al & Si & P & S & K & Ca & Fe \\
\hline$<2 \mu \mathrm{m}$ & 42.92 & 4.3 & 10.68 & 3.49 & 0.41 & 0.29 & 1.63 & 1.06 & 0.42 & 2.25 & 0.34 \\
$2-5 \mu \mathrm{m}$ & 26.66 & 6.65 & 18.52 & 1.94 & 0.79 & 1.76 & 0.68 & 1.05 & 0.33 & 1.62 & 0.75 \\
$5-10 \mu \mathrm{m}$ & 20.88 & 3.9 & 6.76 & 0.64 & 0.27 & 0.59 & 0.17 & 0.66 & 0.16 & 0.91 & 0.46 \\
\hline
\end{tabular}

very little $\mathrm{P}$ in inorganic particles from surface waters (figure $3 b$ ). However, a recent observation of Pan and Krom (pers. comm.) may explain this lack of $\mathrm{P}$ and $\mathrm{Fe}$ association in inorganic particles in the surface water: at the extremely low $\mathrm{P}$ concentrations in surface waters, the inorganic particles desorb $\mathrm{P}$ and presumably become depleted. However, upon reaching deep waters, where $\mathrm{P}$ is relatively abundant, the particles adsorb $\mathrm{P}$. This suggests that organisms may have a higher affinity for $\mathrm{P}$ than Fe inorganic particles and that any removal of bioavailable $P$ from Mediterranean waters by Saharan dust needs to be explained within the framework of models taking vertical transport into account.

The elementary compositions of analysed detrital particles in the three size fractions are compared in table $I$. The $\mathrm{C}$ and $\mathrm{P}$ contents per unit detrital volume were higher in the two smaller size fractions $(<2$ and $2-5 \mu \mathrm{m})$ than in 5-10 $\mu \mathrm{m}$ particles. In contrast, $\mathrm{N}$ content was highest in the $2-5 \mu \mathrm{m}$ particles (figure $3 a$ ). It should be noted here that if the detrital particles had been broken up during the gravity filtration through a $12 \mu \mathrm{m}$ pollycarbonate filter, we would have found the same amounts of $\mathrm{C}, \mathrm{N}$ and $\mathrm{P}$ in the different size classes of detrital particles. The correlation coefficient of $C: P$ ratio and particle sizes was $r=0.57$ (significant with $\mathrm{P}=0.01$ ). The coefficient for $\mathrm{N}: \mathrm{P}$ ratio and particle sizes diminished to $r=0.454$ (significant with $\mathrm{P}=0.05$ ). Both ratios increased for larger particles (figure 4). Thingstad and Rassoulzadegan [32] reported that in Villefranche Bay, $2 / 3(66 \%)$ of the particulate phosphorus $<100 \mu \mathrm{m}$ falls in size fractions $<10 \mu \mathrm{m}$. The $\mathrm{P}$ content of detrital particles in these size fractions can be considered as a source of P-regeneration in the water column.

The C:N:P atomic ratio for different size fractions of detrital particles $(<10 \mu \mathrm{m})$ was $82: 10: 1$ for $<2 \mu \mathrm{m}$ particles, 120:29:1 for 2-5 $\mu \mathrm{m}$ particles and 308:37:1 for $5-10 \mu \mathrm{m}$ particles. The average ratio for all size classes $<10 \mu \mathrm{m}$ of detrital particles was 132:23:1. Thus, the N:P ratio increased in large detrital particles from 10 for
$<2 \mu \mathrm{m}$ particles to 37 in $5-10 \mu \mathrm{m}$ particles. Interestingly, the C:P and $\mathrm{N}: \mathrm{P}$ ratios of $<10 \mu \mathrm{m}$ detrital particles $(132$ and 23 , respectively) were very similar to values reported for those of particulate organic matter in the Ligurian Sea in the northwest Mediterranean [6]. Moreover, our N:P ratio of 23 for $<10 \mu \mathrm{m}$ detrital particles was very similar to 22.5 reported by Coste et al. [8] for the western Mediterranean.

These comparisons indicate that the detrital particles investigated here are poor in phosphorus and rich in nitrogen compared to the other particulate organic matter (POM). A low P-content in detritus is in accordance with the general view that $\mathrm{P}$ is recycled faster than $\mathrm{N}[4,11$, $26,22]$. These ratios fit well with the hypothesis of phosphorus limitation in the Mediterranean Sea [19].

\subsection{General consideration of the origins and contri- butions of pico- and nano-detrital particles within the biogeochemical cycles of an aquatic environment}

There are four possibilities for the origin of pico- and nano- detrital particles $(<10 \mu \mathrm{m})$ : i) decomposition of large detrital particles, such as macrozooplankton fecal pellets; ii) aggregation-coagulation of colloids, as noted for marine snow [1] or dissolved organic carbon (DOC) coagulated by bubbling [24]; iii) solid defecation directly from protozoa $[5,9,12,13,31]$; and iv) "necromass" from dead planktonic organisms. We note here that there is a difference between large detrital particles (fecal pellets) which generally have a peritrophic membrane and fecal aggregates produced by protozoa which do not have a membrane.

If large detrital particles (fecal pellets) had been subjected to microbial consumption or to physical processes (e.g. coprorhexie: [20]), resulting in smaller particle sizes, the latter would contain a low or equal amount of carbon. However, detrital compositions reported here show that $<2 \mu \mathrm{m}$ detrital particles contained much more carbon than the larger sizes. This suggests that the $<2 \mu \mathrm{m}$ particles probably do not result from the decomposition 


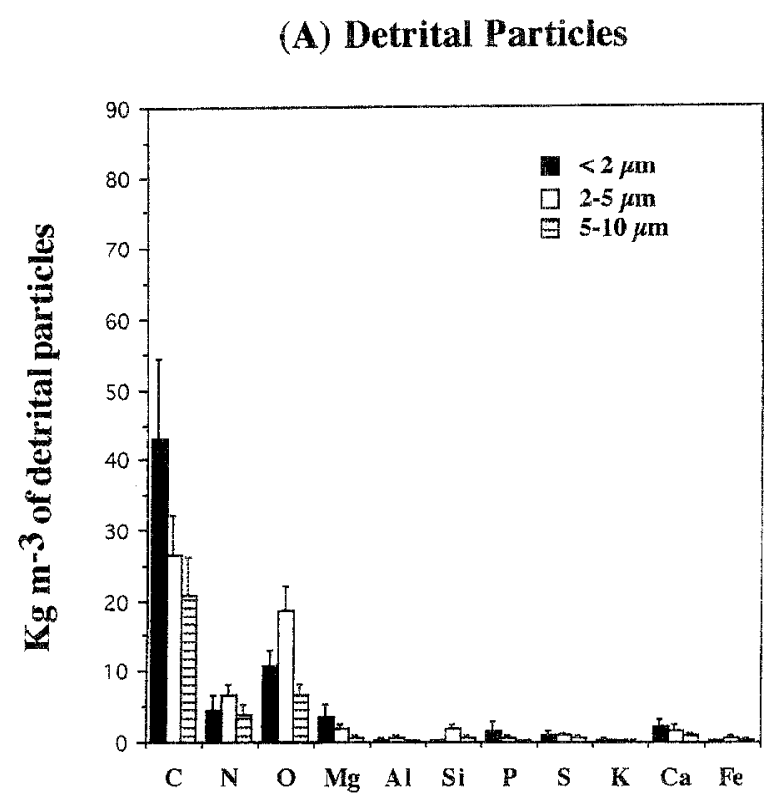

(B) Inorganic Particles

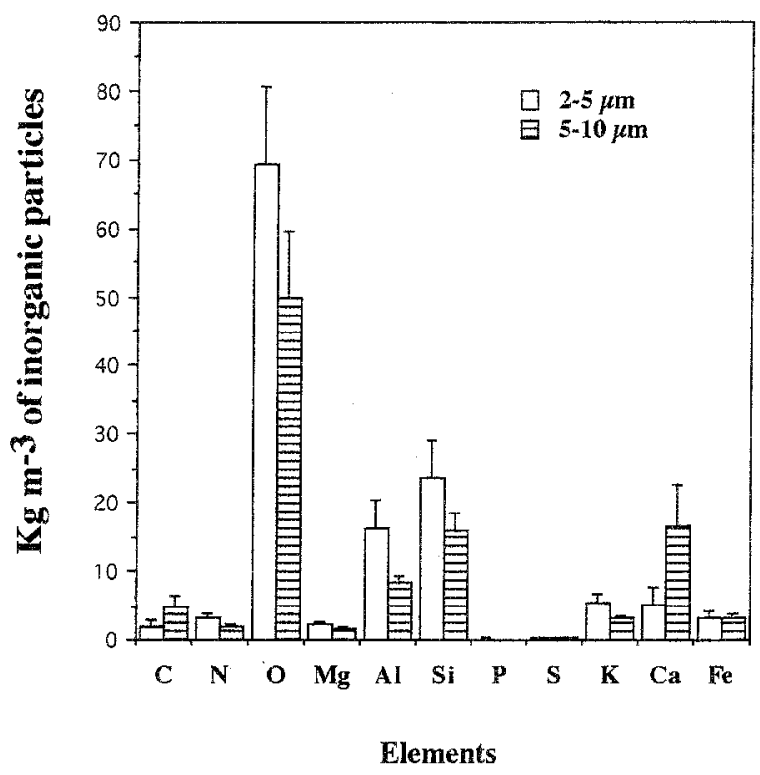

Figure 3. Elemental compositions of three size fractions of pico and nano-detrital particles (A) and two size classes of inorganic par ticles (B) analysed by TEM and X-Ray microanalysis. Bars repre sent standard errors.

or degradation of large particles. This conclusion was drawn previously from a microscopical study of the same detrital particle size classes (Dapi Yellow Particles, [23]).

The second hypothesis for the origin of detrital particles is the aggregation of colloidal particles ( $>1 \mu \mathrm{m},[33]$ ). In

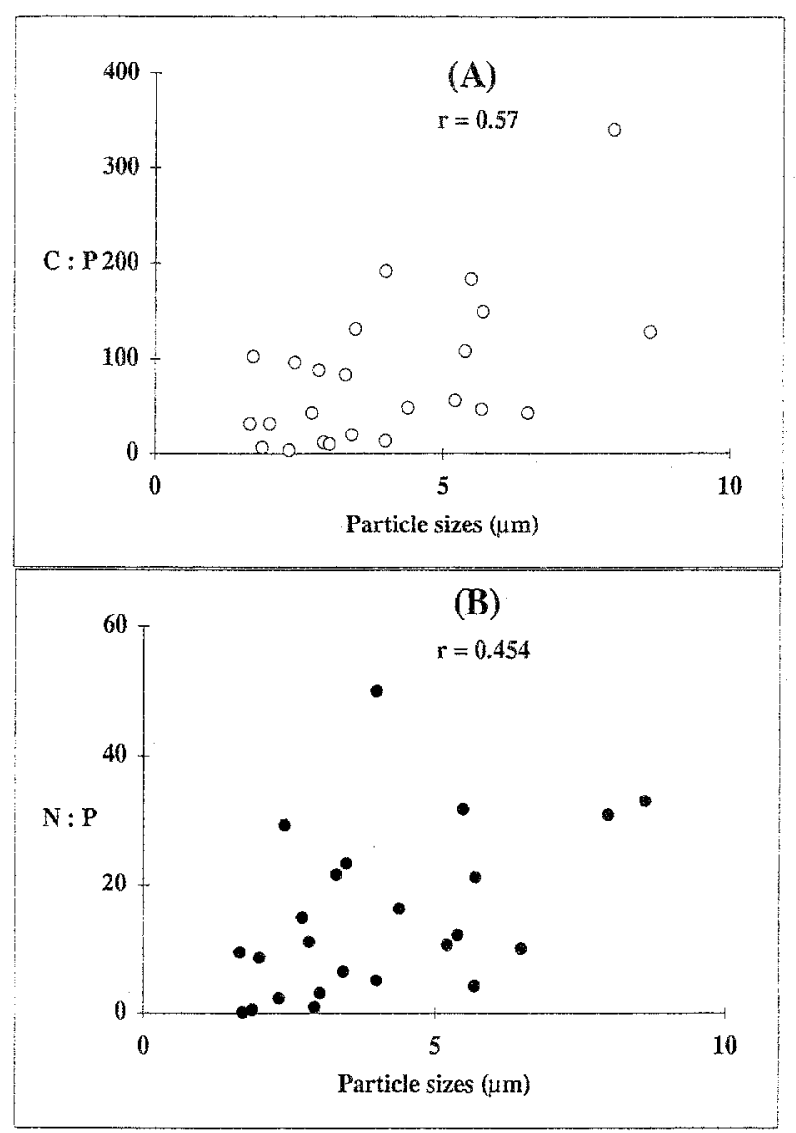

Figure 4. Correlation between $\mathrm{C}: \mathrm{P}$ and $\mathrm{N}: \mathrm{P}$ ratios of detrital particles with their size fractions. Correlation coefficient of C:P ratio and particle sizes is significant at $\mathrm{P}-0.01, \mathrm{r}=0.57(\mathrm{~A})$; and those of $\mathrm{N}: \mathrm{P}$ ratio and particle sizes is significant at $\mathrm{P}=0.05, \mathrm{r}=0.454$ (B).

this case, $<2 \mu \mathrm{m}$ detrital particles might well be expected to contain more carbon than larger particles. The small sizes are the newest, and then as a result of agglomeration-coagulation they produce larger detritus. During this process microbial action can change the ratio of elements either directly, for instance by bacterial colonisation [3], or indirectly, by enzymatic degradation $[17,30]$.

Stoecker [31] clearly showed that fecal aggregates produced by protozoa can disintegrate to give rise to smaller particles; therefore, it is also possible that the detrital particles studied here come from disintegration of fecal aggregates produced by protozoa. The final possibility is that they represent dead planktonic organisms (necromass). The differences in elementary compositions of the detrital particles studied here suggest that the different size fractions probably have different origins. 
Table II. Carbon contribution of different sized fractions of detrital particles to water column compared with those of bacteria at surface water of coastal Mediterranean Sea.

\begin{tabular}{|c|c|c|c|c|}
\hline Particles & $\begin{array}{c}\text { mean diameter } \\
\boldsymbol{\mu \mathrm { m }}\end{array}$ & $\begin{array}{l}\text { Abundance } \\
\text { nb } \mathbf{~ m L}^{-1}\end{array}$ & $\begin{array}{c}\text { Volume } \\
\mu \mathrm{m}^{3} \mathrm{~mL}^{-1}\end{array}$ & $\begin{array}{c}\text { Carbon contribution } \\
\mu \mathrm{g} \mathrm{C} \mathrm{L}{ }^{-1}\end{array}$ \\
\hline$<2 \mu \mathrm{m}$ detrital particles & 1.685 & 3650 & 9137 & 0.392 \\
\hline $2-5 \mu \mathrm{m}$ & 3.234 & 1050 & 18603 & 0.496 \\
\hline $5-10 \mu \mathrm{m}$ & 6.201 & 350 & 43699 & 0.912 \\
\hline Total $<10 \mu \mathrm{m} \quad "$ & & 5050 & 71440 & 1.801 \\
\hline Bacteria* & & 505000 & & 10.1 \\
\hline
\end{tabular}

* Calculated from a mean cell carbon of $20 \mathrm{fg} \mathrm{C}_{\mathrm{C}} \mathrm{cell}^{-1}$ for marine bacteria [35].

We have no direct evidence that the pico- and nano-sized detrital particles studied with TEM are the same particles as the DYPs $[23,24]$. However, we attempted to select particles that resembled morphologically the DYP $<10 \mu \mathrm{m}$ observed under epifluorescence microscope (figure 1). In order to estimate the carbon contribution of detrital particles, the carbon contents of different size classes were extrapolated to the abundances found for DYP in the same sample before filtration through a $12 \mu \mathrm{m}$ polycarbonate filter. Results of DYP counts in the same sample that was analysed by TEM show that small DYP $<2 \mu \mathrm{m}$ were much more abundant than larger DYP (table II).

The carbon contributions of detrital particles in three size fractions of sample are shown in table II. Pico- and nano-detrital particles $<10 \mu \mathrm{m}$ contributed $1.8 \mu \mathrm{g} \mathrm{C} \mathrm{L}^{-1}$ to the carbon content of surface waters of Mediterranean Sea. Bacteria, the dominant component of the planktonic food web, were counted in the same sample and yielded $5.05 \times 10^{5}$ cell $\mathrm{mL}^{-1}$. Assuming the carbon content of marine bacteria to be $20 \mathrm{fg} \mathrm{C}$ cell $^{-1}$ [35], their contri-

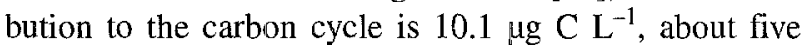
times higher than carbon content of detrital particles $(<10 \mu \mathrm{m})$.
The 'degradable' part of the DOC in Mediterranean surface waters, based on the difference between maximum autumn DOC and the deep water concentrations [7] is estimated to be around $400 \mu \mathrm{g} \mathrm{C} \mathrm{L}^{-1}$ [32]. In other words, the carbon content of detrital particles $<10 \mu \mathrm{m}$ investigated here, represented roughly $1 / 200$ of the DOC at its maximal autumnal concentration.

The physical maintenance (very low settling velocity for particles $<10 \mu \mathrm{m}$ ) and consequential accumulation of this amount of carbon in the surface layer, and high surface/volume ratios would give $<10 \mu \mathrm{m}$ detrital particles a significant role in biogeochemical processes regulating regenerated production in the upper ocean.

\section{Acknowledgments}

The authors thank P. Chang for his help in preparation of samples, S. Norland for his help in statistical treatments, G. Copin-Montégut, C. Copin-Montégut for their valuable comments on the manuscript and E. Houliston for improving the English of the manuscript. Financial support was provided by the CNRS/INSU (URA 716) and E.E.C. MAST II- MTP (Mediterranean Targeted Programme, contract MAST II-CT93-0063, Medipelagos).

\section{REFERENCES}

[1] Alldredge A.L., McGillivary P., The attachment probabilities of marine snow and their implications for particle coagulation in the ocean, Deep-Sea Res. 38 (1991) 431-443.

[2] Alldredge A.L., Gotschalk C.C., The relative contribution of marine snow of different origins to biological processes in coastal watcrs, Cont. Shelf Res. 10 (1990) 41-58.

[3] Biddanda B.A., Pomeroy L.R., Microbial aggregation and degradation of phytoplankton- derived detritus in seawater I. Microbial succession, Mar. Ecol. Prog. Ser. 42 (1988) 79-88.
[4] Bishop J.K.B., Collier R.W., Ketten D.R., Edmond J.M., The chemistry, biology, and vertical flux of particulate matter from the upper $400 \mathrm{~m}$ of the equatorial Atlantic ocean, Deep-Sea Res. 24 (1977) 511-548.

[5] Buck K.R., Newton J., Fecal pellet flux in Dabob Bay during a diatom bloom: Contribution of microzooplankton, Limnol. Oceanogr 40 (1995) 306-315.

[6] Copin-Montégnt C., Copin-Montégut G., Stoichiometry of carbon, nitrogen, and phosphorus in marine particulate matter, Deep-Sea Res. 30 (1983) 31-46. 
[7] Copin-Montégut G., Avril B., Vertical distribution and temporal variation of dissolved organic carbon in the North-Western Mediterranean Sea, Deep-Sea Res. 40 (1993) 1963-1972.

[8] Coste B., Minas H.J., Bonin M._C., Propriétés hydrologiques et chimiques des eaux du bassin occidental de la Méditerranée, Centre National pour l'Exploitation des Océans (CNEXO). Report of cruise No. 26 (1984).

[9] Elbrächter M., Faeces production by dinoflagellates and other small flagellates, Mar. Micro. Food Webs 5 (1991) 189-204.

[10] Fowler S.W., Knauer G.A., Role of large particles in the transport of elements and organic compounds through the oceanic water column. Prog. Oceanogr. 16 (1986) 147-194.

[11] Garber J.H., Laboratory study of nitrogen and phosphorus remineralization during the decomposition of coastal plankton and seston, Estuar. Coast. Shelf. Sci. 18 (1984) 685-702.

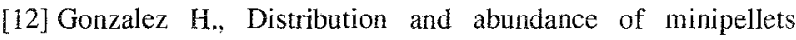
around the Antartic peninscula. Implications for protistan feeding behaviour, Mar. Ecol. Prog. Ser. 90 (1992) 223-236.

[13] Gowing M.M., Silver M.M., Minipellets: a new and abundant size class of marine faecal pellets, J. Mar. Res. 43 (1985) 395 418.

[14] Heldal M., Measurement of elemental content and dry weight of single cells: X-ray microanalysis, in: Handbook of methods in Aquatic Microbial Ecology, Kemp P.F., Sherr B.F., Sherr E.B., Cole J.J. (eds.). Lewis Publishers, Boca Raton. Ann Arbor, London Tokyo, 1993 (1993) 387-394

[15] Heldal M., Norland S., Tumyr O., X-ray microanalytic method for measurement of dry matter and elemental content of individual bacteria, Appl. Environ. Microbiol. 50 (1985) 12511257.

[16] Holm-Hansen O., (1973). Determination of total microbial biomass by measurement of adenosine triphosphate, in: Estuarine microbial Ecology, Stevenson D.S., Colwell R.R., (eds), Belle W. Baruch Library Mar. Sci. v.1, Univ. S.C. 1973, $73-89$.

[17] Karner M., Ferrier-pagès C., Rassoulzadegan F., Phagotrophic nanoflagellates contribute to occurrence of a-glucosidase and aminopeptidase in marine environments, Mar. Ecol. Prog. Ser. 114 (1994) 237-244.

[18] Koike I., Shigemitsu H., Kazuki T., Kazuhiro K., Role of submicrometer particles in the ocean, Nature 345 (1990) 242244.

[19] Krom M.D., Kress N., Brenner S., Phosphorus limitation of primary productivity in the eastern Mediterranean Sea, Limnol. Oceanogr. 36 (1991) 424-432.

[20] Lampitt R.S., Noji T.T., von Bodungen B., What happens to zooplankton fecal pellets? Implications for material flux, Mar. Biol. 104 (1990) 15-23.
[21] Legendre L., Legendre P., Ecologie numérique, Tome 2: Lat structure des données écologiques, $2 e$ éd., Masson, Paris, New York, Barcelone, Milan, Mexico, Sao Paulo, 1984 (1984) 51-104.

[22] Martin J.H., Knauer G.A., Bruland K., Fluxes of particulate carbon, nitrogen and phosphorus in the upper water column of the northeast Pacific, Deep-Sea Res. 26 (1979) 97-108.

[23] Mostajir B., Dolan J.R., Rassoulzadegan F., A simple methodology for the quantification of a class of labile marine Picoand Nano-sized detritus: DAPI Yellow Particles (DYP), Aq. Microb. Ecol. 9 (1995a) 259-266.

[24] Mostajir B., Dolan J.R., Rassoulzadegan F., Seasonal variations of Pico- and Nano-Detrital Particles (Dapi Yellow Particles "DYP") in the Ligurian Sea, North Western Mediterranean, Aq. Microb. Ecol. 9 (1995b) 267-277.

[25] Norland S., Fagerbakke K.M., Heldal M., Light element analysis of individual bacteria by X-ray microanalysis, Appl. Environ. Microbiol. 61 (1995) 1357-1362.

[26] Redfield A.C., Ketchum B.H., Richards F.A., The influence of organisms on the composition of sea-water, in: The sea, Hill M.N., (ed.). 1963 (Vol 2) (1963) 26-77.

[27] Riemann B., Bell R.T., Advances in estimating bacterial biom mass and growth in aquatic systems, Arch. Hydrobiol. 118 (1990) 385-402.

[28] Sakshaug E., Problems in the methodology of studying phytoplankton, in: The physiological ecology of phytoplankton, Morris L. (ed.), Blackwell, 1980, 57-91.

[29] Sieracki M., Viles C., Distribution and fluorochrome-staining of sub-micrometer particles and bacteria in the North Atlantic, Deep-Sea Res. 39 (1992) 1919-1929.

[30] Smith D.C., Simon M., Alldredge A.L., Azam F., Intense hydrolytic enzyme activity on marine aggregates and implications for rapid particle dissolution, Nature 359 (1992) 139-142.

[31] Stoecker D.K., Particle production by planktonic ciliates, Limnol. Oceanogr. 29 (1984) 930-940.

[32] Thingstad T.F., Rassoulzadegan F., Nutrient limitations, microbial food webs, and 'biological C-pumps': suggested interactions in a P-limited Mediterranean, Mar. Ecol. Prog. Ser. 117 (1995) 299-306.

[33] Wells M.L., Goldberg E.D., Colloid aggregation in sea water, Mar. Chem. 41 (1993) 353-358.

[34] Wells M.L., Goldberg E.D., The distribution of colloids in the North Atlantic and Southern Oceans, Limnol. Oceanogr 39 (1994) 286-302.

[35] Zweifel U.L., Norrman, Hagström A., Consumption of dissolved organic carbon by marine bacteria and demand for inorganic nutrients, Mar. Ecol. Prog. Ser. 101 (1993) 23-32. 